\title{
Einladung zur Mitgliederversammlung des Vereins Ultraschallmuseum e. V. 2012 in Davos
}

Sehr geehrte Frau Kollegin, sehr geehrter Herr Kollege,

hiermit lade ich Sie ganz herzlich zu unserer diesjährigen Mitgliederversammlung ein.

Zeitpunkt Donnerstag, der 27. September 2012, 13-14 Uhr

Ort Kongresszentrum Davos - während des DLT

Raum steht im Programmheft bzw. am Museumsstand
Tagesordnung

1. Genehmigung des Protokolls der letzten MV

2. Bericht des Vorsitzenden

3. Internetseiten

4. Filmprojekt

5. Finanzbericht

6. Entlastung des Vorstands

7. Neuwahl des Vorstands

8. Verschiedenes

B. Frentzel-Beyme, Vorsitzender 